Shamayim: Jurnal Teologi dan Pendidikan Kristiani

Volume 1, Nomor 1, 2020 (14-28)

http://hologos.college/ejournal/index.php/shamayim/index

\title{
Peran Guru Dalam Menerapkan Pendidikan Agama Kristen Untuk Menumbuhkan Iman Kristen Anak Sejak Dini
}

\author{
Sriyanti \\ Sekolah Tinggi Agama Kristen Terpadu Pesat Salatiga \\ sriyantigamba@gmail.com \\ Esen Hon Nakamnanu \\ Sekolah Tinggi Agama Kristen Terpadu Pesat Salatiga \\ esenhon12@gmail.com
}

\begin{abstract}
The application of Christian faith is not only knowledge to add insight into Christianity, but the application of education is a way to be able to cultivate Christian faith in every child. The application of Christian education is not limited to being applied from primary school to university but is applied to start from early childhood education (PAUD). In the application of Christian education, teachers have an important role in faith growth because Christian education implemented in Sion Tridamarsari Kindergarten aims to foster faith in every child through Christian education. Before applying the Christian education, teachers need to realize that being a PAUD teacher is not just a job or a profession but is a calling from God so that teachers will be able to understand that the growth of Children's Christian faith must be implemented from an early age. The type of research in this article is qualitative research. Where every informant is interviewed and observed. Based on the result that has been done, the role of the teachers in implementing Christian education for children is teachers can put themselves as friends, pastors, evangelists, facilitators, mentors, motivators, and role models. With these roles, can help and assist each child in the growth of faith that is achieved, namely believing that Jesus Christ is Lord and Savior, dare to pray for himself and others, distinguishing right and wrong actions and helping others. This achievement requires a continuous process and is carried out for a long time. By implementing Christian education it has an impact on the growth of Christian faith from an early age.
\end{abstract}

Key words: Teacher, Rolling and Faith

\section{Abstrak}

Penerapan pendidikan iman Kristen pada intinya bukan sebagai pengetahuan untuk menambah wawasan mengenai agama Kristen, akan tetapi penerapan pendidikan merupakan suatu cara untuk dapat menumbuhkan iman Kristen dalam pribadi anak. 
Penerapan pendidikan Agama Kristen tidak sebatas diterapkan dari pendidikan dasar sampai pada perguruan tinggi, tetapi diterapkan mulai dari pendidikan anak usia dini (PAUD). Dalam penerapan pendidikan agama Kristen, guru mempunyai peran penting terhadap pertumbuhan iman karena pendidikan agama Kristen yang diterapkan di Taman Kanak-Kanak Sion Tridamarsari bertujuan untuk menumbuhkan iman Kristen anak sejak dini yaitu pada usia empat sampai enam tahun. Sebelum menerapkan pendidikan agama Kristen, guru Taman Kanak-Kanak Sion Tridamarsari perlu menyadari bahwa menjadi guru PAUD bukanlah merupakan suatu pekerjaan atau profesi saja tetapi sebuah panggilan dari Tuhan, sehingga guru akan dapat mengerti bahwa pertumbuhan iman Kristen anak haruslah diterapkan sejak usia dini. Jenis penelitian dalam tulisan ini adalah penelitian kualitatif. Di mana setiap informan diwawancarai dan diobservasi. Berdasarkan hasil yang telah dilakukan, peran guru dalam menerapkan pendidikan agama Kristen pada anak harusnya guru mampu memposisikan diri sebagai sahabat, gembala, penginjil, fasilitator, pembimbing, motivator, dan teladan, dengan peran tersebut dapat membantu dan menolong setiap anak dalam pertumbuhan iman yang dicapai yaitu percaya bahwa Yesus Kristus adalah Tuhan dan Juruselamat, berani berdoa untuk dirinya dan orang lain, membedakan perbuatan yang benar dan yang salah dan menolong sesama atau orang lain. Pencapaian tersebut membutuhkan proses secara terus menerus dan dilakukan dalamwaktu yang lama. Dengan menerapan pendidikan agama Kristen berdampak terhadap pertumbuhan iman Kristen sejak dini.

Kata kunci: Guru, Peranan dan Iman

\section{Pendahuluan}

Guru merupakan pendidik yang memiliki peranan penting dalam membentuk anak menjadi pribadi yang dewasa. ${ }^{1}$ Guru adalah figur manusia yang menempati posisi dan memegang peran penting dalam pendidikan. Menurut Djamarah guru adalah "orang yang memberikan ilmu pengetahuan kepada anak didik. Dalam pandangan masyarakat guru adalah orang yang melaksanakan pendidikan di sekolah. Guru bukan saja melakukan pendidikan di tempat formal saja tetapi bisa dimana saja, bisa di rumah, di gereja dan sebagainya. $^{2}$

Dengan demikian guru berfungsi di semua tempat. Guru menjadi pribadi yang perlu di contoh dalam kehidupan bermasyarakat. Ketika terjadi persoalan dalam dunia pendidikan, figur guru akan dilibatkan dalam agenda pembicaraan utama yang menyangkut persoalan pendidikan formal di sekolah. Hal ini tidak dapat disangkal karena lembaga pendidikan formal adalah dunia kehidupan guru.

Homrighausen menjelaskan bahwa Guru Kristen adalah Pertama- tama, menjadi penafsir iman Kristen, artinya guru yang menguraikan dan menerangkan kepercayaan

${ }^{1}$ Sudiria Hura and Marde Christian Stenly Mawikere, "KAJIAN BIBLIKA MENGENAI PENDIDIKAN ANAK DAN HAKIKAT PENDIDIKAN ANAK USIA DINI," EDULEAD: Journal of Christian Education and Leadership 1, no. 1 (2020): 15-33.

${ }^{2}$ Friedrich Froebel, The Education of Man, vol. 5 (A. Lovell \& Company, 1910). 31 
Kristen itu, karena diharuskan menyampaikan harta- harta dari masa lampau kepada para pemuda yang akan menempuh masa depan. Kedua, guru juga menjadi gembala bagi muridmuridnya. Guru bertanggung jawab atas hidup rohani anak, dan wajib membina dan memajukan hidup rohani itu. Ketiga, guru harus menjadi pemimpin, artinya tidak menuntun setiap anak- anak untuk masuk ke kepercayaan Kristen dengan paksa, melainkan harus membimbing anak secara pelan dan halus kepada Juruselamat yang hidup. Guru harus menjadi teladan dan mencerminkan roh Kristus dalam seluruh pribadinya. Dan yang Keempat, guru harus menjadi seorang penginjil, artinya bertanggung jawab atas penyerahan diri setiap para peserta didik atau anak- anak usia dini kepada Yesus Kristus. Karena tujuan adalah supaya setiap anak dapat sungguh- sungguh menjadi murid- murid Tuhan Yesus. Guru juga tak boleh puas sebelum anak didiknya menjadi orang Kristen yang sejati. ${ }^{3}$ Selanjutnya menjadi tanggungjawab guru sebagai pendidik untuk memperkenalkan Kristus dalam kehidupan setiap siswa. ${ }^{4}$

Pendidikan Agama Kristen pada umumnya tidak hanya diberikan oleh gereja dalam lingkungan tertentu, tetapi juga di sekolah umum. Sesungguhnya, agama dan pendidikan tidak dapat dipisahkan. Pendidikan agama sangat memperkuat iman dan karakter anak didik, sedangkan pendidikan umum meningkatkan kamampuaan dalam segi kognitifnya. Dengan demikian, apabila kedua hal ini saling melengkapi, maka akan menghasilkan anak didik yang berkualitas baik dalam karakter maupun kognitif anak. ${ }^{5}$

Dalam hal ini Robert W. Pazmino mengungkapkan bahwa pendidikan agama kristen merupakan:

"Usaha bersahaja dan sistematis, ditopang oleh upaya rohani dan manusiawi untuk mentransmisikan pengetahuan, nilai-nilai, sikap-sikap, keterampilan-keterampilan dan tingkah laku yang bersesuaian/ konsisten dengan iman Kristen; mengupayakan perubahan, pembaharuan, dan reformasi pribadi-pribadi, kelompok bahkan struktur oleh Kuasa Roh Kudus sehingga peserta didik hidup sesuai dengan kehendak Allah sebagaimana dinyatakan oleh Alkitab, terutama dalam Yesus Kristus.” 6

Berdasarkan pemahaman di atas, maka dapat disimpulkan bahwa pendidikan agama Kristen merupakan kegiatan rohani dan manusiawi baik yang berkaitan dengan pengetahuan, nilai-nilai, sikap-sikap, ketrampilan-ketrampilan dan tingkah laku yang sesuai dengan iman Kristen sehingga menyadarkan seseorang mengenai dosa dan mampu hidup sesuai dengan kehendak Allah.

Dari kutipan uraian di atas menunjukkan bahwa pendidikan agama mutlak diperlukan untuk menumbuhkan iman sejak usia dini, oleh sebab itu guru agama yang

\footnotetext{
${ }^{3}$ Elmer George Homrighausen and Ido Hendricus Enklaar, Pendidikan Agama Kristen (Badan Penerbit Kristen, 2015). Hal. 164-165

4 Romini Romini and Ida Destariana Harefa, "MANFAAT PENGGUNAAN ALKITAB BERGAMBAR TERHADAP PERKEMBANGAN KEROHANIAN ANAK FUTURE CENTER USIA 7-9 TAHUN DI BULUH AWAR," EDULEAD: Journal of Christian Education and Leadership 1, no. 1 (2020): $1-14$.

5 GP Harianto, "Pendidikan Agama Kristen Dalam Alkitab Dan Dunia Pendidikan Masa Kini," Yogyakarta: Yasasan Andi (2012). Hal 124

${ }^{6}$ B Samuel Sidjabat, Strategi Pendidikan Kristan (Yayasan ANDI, 1994). Hal 10
} 
mengajar sangat bertanggung jawab dalam menumbuhkan iman Kristen sejak usia dini. Guru harus menanamkan nilai-nilai agama kepada setiap anak didiknya dengan berbagai cara. Akan tetapi tujuan itu tidak akan tercapai apabila tidak adanya kerjasama dengan semua pihak terutama dengan sesama guru dan orang tua anak didik. Sebab pendidikan agama akan terbina apabila adanya kesinambungan atau keterpaduan antara pembinaan orang tua didalam keluarga, masyarakat dan guru di sekolah.

Mary mengungkapkan bahwa masa petumbuhan iman pada usia empat sampai enam tahun adalah pengenalan akan kasih Yesus Kristus yaitu melalui kasih orang dewasa terhadap dirinya, iman kepada Allah dinyatakan dengan rasa percayanya terhadap orang dewasa, selalu berdoa sebelum dan sesudah melakukan kegiatan dengan sikap berdoa yang benar, memiliki kesadaran terhadap hal-hal yang benar (mengucapkan kata-kata yang santun), menolong teman dan orang dewasa. ${ }^{7}$

Demikian dengan guru Taman Kanak-Kanak (TK) Sion Tri Damarsari, Dusun Purwosari, Desa Sampetan, Kecamatan Ampel, Kabupaten Boyolali, Provinsi Jawa Tengah, dalam menumbuhkan iman Kristen sejak usia dini tidak terlepas dari peran guru di sekolah, orang tua di rumah dan masyarakat lingkungannya. Peranan guru TK Sion Tridamarsari sangat penting untuk menumbuhkan iman anak. Guru-Guru TK Sion Tridamarsari menyadari bahwa pertumbuhan iman anak sangat penting untuk ditingkatkan akan tetapi guru-guru yang ada dalam proses kegiatan belajar mengajar lebih mengutamakan kognitif anak dari pada pertumbuhan iman anak. Guru-guru lebih mengutamakan tuntutan dari sekolah dasar untuk anak-anak dapat menulis dan membaca tanpa mengajarkan tentangan Iman kepada Yesus Kristus. Pada intinya enam guru yang ada merupakan lulusan dari lembaga misi PESAT yang mempunyai misi kedepan yaitu membawa setiap peserta didik untuk mengenal, dan mengalami perjumpaan dengan Yesus Kristus. Sehingga pada kenyataannya sekarang masih ada banyak anak didik yang ada di Taman Kanak-Kanak Tridamarsari yang belum bertumbuh imannya seperti pemahaman akan Yesus Kristus masih minim, kurangnya keberanian dalam berdoa dan kesadaran terhadap pentingnya berdoa, kurangnya kesadaran akan hal-hal yang salah dan benar atau yang baik dan yang jahat dan kurangnya mempraktikan kasih (tolong menolong) terhadap sesama sesuai pengajaran Kristus. Dengan demikian peranan guru di sekolah dibutuhkan dalam menumbuhkaniman Kristen sejakdini. Sehingga perananan guru sangat penting untuk diketahui untuk menumbuhkan iman Kristen pada tiga belas anak TK A dan TK B usia lima sampai enam tahun di TK Sion Tridamarsari.

\section{Metode Penelitian}

Dalam arti kata yang sesungguhnya, maka metode (Yunani: methodos) adalah cara atau jalan. Sehubungan dengan upaya ilmiah, maka metode menyangkut masalah cara kerja; yaitu cara kerja untuk dapat memahami obyek yang menjadi sasaran ilmu yang bersangkutan. ${ }^{8}$ Sedangkan menurut Sugiyono penelitian adalah seperangkat pengetahuan

\footnotetext{
${ }^{7}$ Ibid. 33 \& 61-62

${ }^{8}$ Fuad Hasan, Koentjaraningrat, Metode-Metode Penelitian Masyarakat (Jakarta: Gramedia, 1970).
}

Hal. 7 
tentang langkah- langkah sistematis dan logis mengenai pencarian data yang berkenaan masalah tertentu yang kemudian diolah, dianalisis dengan kesimpulan hingga dicarikan satu pemecahan atas suatu masalah. Jadi dapat disimpulkan bahwa metode penelitian adalah cara ilmiah untuk mendapatkan data dengan tujuan dan kegunaan tertentu. ${ }^{9}$

Metode penelitian yang digunakan dalam "Peranan Guru Dalam Menerapkan Pendidikan Agama Kristen Untuk MenumbuhkanIman Kristen Sejak Dini”, adalah metode kualitatif. Metode penelitian kualitatif adalah metode penelitian yang berlandaskan padafilsafat postpositivisme, digunakan untuk meneliti pada kondisi obyek yang alamiah, (sebagai lawannya adalah eksperimen) dimana peneliti adalah sebagai instrument kunci, pengambilan sampel sumber data dilakukan secara porposiv dan snowbaal, teknik pengumpulan dengan trianggulasi (gabungan), analisis data bersifat induktif/kualitatif, dan hasil penelitian kualitatif lebih menekankan makna dari pada generalisasi. ${ }^{10}$ Metode kualitatif berusaha memahami dan menafsirkan makna suatu peristiwa interaksi tingkah laku manusia dalam situasi tertentu menurut perspektif peneliti sendiri. ${ }^{11}$ Berdasarkan pengertian ini, dapat disimpulkan bahwa metode penelitian kualitatif adalah metode yang digunakan untuk meneliti pada objek yang alamiah dan peneliti sebagai kunci dalam pengambilan data.

\section{Pembahasan dan Hasil}

Guru adalah seseorang yang meluangkan segala pemikirannya untuk mengajar anak yang dididik dengan segala kemampuan, ${ }^{12}$ yang dapat dikatakan dalam kesehariannya bertugas mengajar dan mendidik seseorang atau sekelompok orang. Dalam mendefinisikan guru, banyak sekali yang dapat ditemukan pengertian dari guru tersebut, tetapi dapat didefinisikan bahwa guru adalah pendidik profesional. ${ }^{13}$ Tugas utamanya adalah mendidik, mengajar, membimbing, mengarahkan dan juga melatih, menilai serta mengevaluasi peserta yang dididik pada pendidikan formal di jenjang anak usia dini, pendidikan dasar, dan menengah.

Guru sebagai pendidik profesional mempunyai citra diri yang baik di masyarakat apabila dapat menunjukan kepada masyarakat bahwa layak menjadi panutan atau teladan masyarakatnya. ${ }^{14}$

Berdasarkan penjelasan diatas dapat disimpulkan bahwa guru adalah seorang tenaga profesional yang dalam kesehariannya meluangkan segala pemikiran untuk mengajar dan mendidik seseorang atau sekelompok orang.

\section{Guru PAK}

9 S Sugiyono, "Metode Penelitian Pendidikan Pendekatan Kuantitatif, Dan R\&D," Alfabeta Bandung (2015). Hal 2

${ }^{10}$ Prof Dr Sugiyono, "Metode Penelitian Pendidikan,” Pendekatan Kuantitatif (2010). Hal 15

${ }^{11}$ Husaini Usman and Purnomo Setiady Akbar, Metodologi Penelitian Sosial (Bumi Aksara, 2008).

Hal 81

${ }^{12}$ Harianto, "Pendidikan Agama Kristen Dalam Alkitab Dan Dunia Pendidikan Masa Kini.”Hal 154

${ }^{13}$ Maximus Sembiring, Mengungkap Rahasia Dan Tips Manjur Menjadi Guru Sejati (Galangpress, 2008). Hal 34

${ }^{14}$ Raflis Kosasi Soetjipto, “Profesi Keguruan,” Jakarta: Rineka Cipta (2009). Hal 42 
Guru PAK adalah seorang yang pekerjaannya mengajar orang lain atau orang yang dicontohi dalam perkataan dan perbuatannya. Guru pendidikan agama Kristen adalah sebuah profesi yang tugas utamanya mendidik, mengajar, membimbing dan melatih setiap peserta didik untuk dapat bertumbuh secara rohani. Sebagai guru Kristen harus memiliki kualitas seperti tanggung jawab dan disiplin karena sebagai guru agama Kristen harus dapat mengembangkan sikap, watak, nilai moral dan potensi peserta didik untuk menjadi dewasa secara rohani serta beriman dan taat kepada Tuhan Yesus. ${ }^{15}$

\section{Peran guru PAK}

Peran guru agama Kristen dalam PAK sangat penting dalam membentuk kepribadian anak untuk mewujudkan anak- anak yang saleh. ${ }^{16}$ Dalam Amsal 22: 6, "Didiklah orang muda menurut jalan yang patut baginya, maka pada masa tuanyapun ia tidak akan menyimpang dari jalan itu."

Peran guru ialah mengajarkan teori tentang nilai- nilai yang harus ditarapkan anakanak untuk memiliki kepribadian yang beriman kepada Yesus.Selain itu, guru juga berperan memberikan teladan dalam menarapkan nilai- nilai yang diajarkan. Dengan demikian peserta didik dapat meneladaninya. Sebagai pembina, guru juga harus memantau dan mengawasi anak-anak dalam menerapkan nilai kristiani yang telah diajarkan. Bila menemukan kesalahan atau hal yang kurang tepat dalam penerapan tersebut, guru langsung membetulkannya dengan berbagai cara yang dianggap tepat dan memungkinkan peserta didik memperbaiki perilakunya. Dengan demikian sesungguhnya pendidik dalam PAK mampu untuk memilih kehidupan, dan untuk menjalani masa kini secara manusiawi dan dengan sukacita, dan saat yang sama juga guru PAK mempunyai tugas dan tanggung jawab untuk menolong orang lain menjalani kehidupannya seperti itu juga dalam Yesus Kristus. ${ }^{17}$

Setiap pendidik harus memiliki persepsi yang benar mengenai perannya sebagi pendidik. Beberapa hal yang menyangkut persepsi tentang peran pendidik adalah sebagai berikut: ${ }^{18}$

1) Sebagai Wakil Kristus

Guru juga merupakan wakil Tuhan.Anak- anak dipandang sebagai anak Allah, penebusan darah Yesus Kristus menjadikan anak-anak sebagai anggota keluarga ilahi. Namun perlu diketahui bahwa guru Kristen atau pelayanan para pendidik dalam PAK bukan terutama untuk memberitakan, melainkan membentuk dan mendidik anak- anak agar memperaktikan berita injil. Namun juga perlu diingat, firman haruslah diterapkan dalam kehidupannya (sebagi pendidik) terlebih dahulu.

2) Sebagai Sahabat

Sebagai sahabat, pendidik dapat menolong peserta didiknya untuk merasa diterima, dihargai, dan dianggap penting. Selanjutnya, hal ini akan memberi

${ }^{15}$ Thomas H Groome, Christian Religious Education (BPK Gunung Mulia, 2015). Hal. 49-60

${ }^{16}$ John M Nainggolan, Strategi Pendidikan Agama Kristen (Generasi Info Media, 2008). Hal 160

${ }^{17}$ Nuhamara Daniel, Pembimbing Pendidikan Agama Kristen (Bandung: Jurnal Info Media, 2009). Hal 167-169

${ }^{18}$ Harianto, "Pendidikan Agama Kristen Dalam Alkitab Dan Dunia Pendidikan Masa Kini.”hal 157 
pengaruh positif dalam pengembangan potensi peserta didik sesuai dengan anugerah Allah.

\section{Tugas dan Tanggung Jawab guru PAK}

Dalam hal ini pendidik juga bertugas dan bertanggung jawab sebagai: ${ }^{19}$

1. Menjadi penafsir iman Kristen yaitu menguraikan dan menerapkan kepercayaan Kristen. Guru harus menyampaikan pernyataan Allah dalam Yesus Kristus sebagaimana tersimpan dalam Alkitab kepada anak- anak.

2. Menjadi gembala bagi peserta didiknya yaitu Gurubertanggung jawab atas kehidupan rohani anak, guru wajib membimbing dan memajukan kehidupan rohani anak. Tuhan Yesus sudah memerintahkan kepadanya: "Peliharakalah segala anak domba-Ku, gembalakanlah segala domba-Ku!" oleh karena itu, seharusnya pendidik mengenal anak- anak didiknya, bukan hanya nama, melainkan latar belakang kehidupan pribadinya.

3. Menjadi teladan dan pemimpin artinya gurutidak boleh menuntut anak- anak masuk kedalam kepercayaan Kristen dengan terpaksa, melainkan harus membimbing mereka dengan tulus dan lemah lembut kepada Juruselamat dunia. Oleh karena itu, hendaklah guru menjadi teladan yang menarik orang kepada Kristus sehingga seluruh kepribadiannya mencerminkan Roh Kristus.

4. Menjadi penginjil yang bertanggung jawab atas penyerahan diri setiap peserta didiknya kepeda Yesus Kristusartinya belum cukup jika hanya menyampaikan segala pengetahuan tentang Kristus kepada anak-anak, tetapi tujuan pengejaran itu ialah menjadikan setiap anak- anak menjadi murid Tuhan Yesus yang setia. Seorang pendidik tidak boleh merasa puas sebelum anak didiknya menjadi orang Kristen sejati.

5. Menjadi fasilisatorartinya menyediakan materi bagi anak didiknya menuju kedewasaan dalam iman kepada Yesus Kristus.

6. Menjadi pembimbing artinyaseorang pendidik harus menjadi pembimbing sekaligus penunjuk jalan dalam proses belajar mengajar. Dalam hal ini, pendidik bertugas membimbing anak didiknya kepada tujuan pengenalan akan Yesus Kristus secara lebih mendalam.

7. Menjadi motivatorartinya seorang yang harus menolong anak didiknya untuk mempunyai hasrat belajar tentang iman Kristiani

\section{Pendidikan Agama Kristen}

Pendidikan agama Kristen merupakan pendidikan yang berporos pada pribadi Tuhan Yesus Kristus dan Alkitab (Firman Allah) sebagai dasar atau sumber. ${ }^{20}$ Menurut Marthin Luther pendidikaan agama Kristen adalah pendidikan yang melibatkan warga jemaat untuk belajar teratur dan tertib agar semakin menyadari dosanya serta sukacita didalam Firman Yesus Kristus yang memerdekakan. Di samping itu pendidikan agama Kristen

\footnotetext{
${ }^{19}$ Ibid. hal. 158 dan 159

${ }^{20}$ Lilik Kristianto Paulus, Prinsip \& Praktik Pendidikan Agama Kristen (Yogyakarta: Andi Offset, 2015). Hal 1
} 
memperlangkapi warga jemaat dengan pengalaman berdoa, Firman tertulis (Alkitab) dan rupa - rupa kebudayaan sehingga warga jemaat mampu melayani sesamanya termasuk masyarakat dan negara serta mengambil bagian dengan bertanggung jawab dalam persekutian Kristen. ${ }^{21}$

Dengan mengutip pengertian pendidikan agama Kristen yang diutarakan diatas maka disimpulkan bahwa pendidikan agama Kristen adalah pendidikan yang mengajarkan kepada anak - anak dalam mengenal pribadi Yesus Kristus dengan Karya PenyelamatanNya dan diperlengkapi dengan Firman Yesus Kristus.

\section{Landasan Teologi Pendidikan Agama Kristen}

Pendidikan agama Kristen merupakan proses pembelajaran yang berdasarkan pengetahuan Alkitab, berpusat pada Kristus dan Firman Tuhan sebagai dasar guna mempersiapkan manusia sehingga menjadi bait Allah. Namun dalam hal ini untuk lebih memahami pendidikan agama Kristen dari sisi teologi maka diuraikan dasar teologis Pendidikan Agama Kristen itu sendiri, sehingga tidak hanya pengertian Pendidikan Agama Kristen itu saja yang diketahui bahkan dasar teologi pendidikan agama Kristen sangat penting diketahui.

Ada beberapa dasar-dasar teologi pendidikan agama Kristen menurut para ahli yaitu:

1. Martin Luther

Menurut Luther ada empat dasar teologis agama Kristen yaitu: ${ }^{22}$

a. Keadaan berdosa setiap warga

Banyak teolog lain yang juga mengakui dosa asal, tetapi pengakuan itu cendrung tetaplah sebuah pengajaran. Namun berbeda dengan yang melalui pengalamannya mendorongnya untuk mencari jalan keluar yang mengenyangkan kelaparan jiwa, yang menurutnya tidak bisa diatas melalui seluk beluk sistem sakramental yang merupakan soko - guru gereja zamannya.

b. Pembenaran oleh iman

Melalui penderitaan jiwanya Luther diyakinkan kebenaran dosa sebagai faktor dalam diri setiap orang. Dosa meresap ke dalam sebuah kebajikan insane disamping tindakannya yang buruk.

c. Imamat setiap orang percaya

Sebenarnnya semua oleh iman telah dijadikan makhluk baru dalam Yesus Kristus. Dengan kata lain setiap warga adalah imam bagi warga seimannya.

d. Firman Allah

Dasar teologi ini sudah terdapat dalam tiga dasar lainnya karena semua berakar dalam Alkitab, yaitu Yesus secara pribadi dan ajaran-Nya adalah Firman Allah, Alkitab sebagai firman dan firman.

${ }^{21}$ Ibid. hal 2

${ }^{22}$ Robert R Boehlke, Sejarah Perkembangan Pikiran \& Praktek Paki (BPK Gunung Mulia, 1994). Hal 321-323 
2. Friedric W.A. Froebel ${ }^{23}$

Menurut Froebel ada beberapa hal yang menjadi dasar teologi pendidikan agama Kristen antara lain:

a. Ajaran tentang Allah

Segala sesuatu perlu menyiapkan hakikatnya, yaitu kesatuan ilahi itu sendiri, segala sesuatu itu harus menyatakan Allah, baik melalui inti lahirnya maupun tidak kekal, karena berbuat demikian adalah maksud panggilan hidupnya.

b. Pengertian tentang Yesus

Ucapan Yesus yang sering diulangi, "Percayalah kepadaKu", berarti "Anda sebagai ciptaan Allah yang berasal dari debu tanah dapat merasa mengetahui bahwa sebetulnya apa yang luhur tentang manusia yaitu asal - usulnya yang ilahi dan ketergantungan dengan Allah sudah dinyatakan dengan jelas dalam hidupku".

c. Pengertian teologi tentang manusia

Artinya setiap orang hendaklah dilihat dan diperlukan sebagai pengejawatantahan dari Roh Allah dalam rupa seorang manusia yang tersilat juga manusia adalah karunia Allah, merupakan anak Allah yang secara harmonis dan menyatu dalam mempermuliakan nama-Nya.

\section{C.L.J Sherrill ${ }^{24}$}

Menurut Sherrrill ada tiga teologis utama sebagai dasar pendidikan agama Kristen yakni:

a. Ajaran tentang pernyataan

Pernyataan sebagai penyikapan diri yang dinyatakan dalam perjumpaan antara Allah dengan manusia bukanlah keterangan tentang Allah, melainkan Allah sendiri sebagai diri pribadi.

b. Ajaran tentang manusia

Dalam satu pihak dialah tokoh yang gagal dalam mencapai kemungkinannya yang luas, yang cenderung memutuskan hubungannya dengan sesamanya dan dengan Allah akan tetapi dari pihak lain dialah tokoh yang berbahagia, karena diciptakan untuk hidup dalam persekutuan.

c. Persekutuan Kristen

Persekutuan ini dirumuskan sebagai kumpulan yang berdampak bagi anggotanya sebagai diri pribadi yang utuh dan mengatasnamakan Tuhan Yesus dalam persekutuan.

\section{Hasil}

Taman kanak-kanak Sion Tridamarsari adalah suatu lembaga pendidikan yang dikelola atau dibawah tanggung jawab yayasanPESAT yang merupakan tempat persiapan anak-anak usia empat sampai enam tahun dalam belajar sebelum melanjutkan pendidikan ke sekolah dasar.

\footnotetext{
${ }^{23}$ Froebel, The Education of Man, vol. 5, p. .. hal 1-2

${ }^{24}$ Robert R Boehlke, Sejarah Perkembangan Dan Praktek PAK: Dari Yohanes Amos Comenius Hingga Perkembangan PAK Di Indonesia (Jakarta: BPK-Gunung Mulia, 2011). Hal. 714-720
} 
Taman Kanak-Kanak Sion Tridamarsari pertama kali dirintis oleh beberapa orang PESAT yaitu ibu DP, ibu ND, ibu M, ibu E, pada tanggal 16 Juni 2001. Perintisan Taman Kanak- Kanak Sion Tridamarsari didasari karena kecintaan PESAT terhadap pendidikan anak usia dini. Dalam perjalanan sejarah berdirinya Taman Kanak-Kanak Sion Tridamarsari, banyak mendapat pro dan kontra dari pihak masyarakat setempat. Sebagai permasalahnnya dianggap pihak dari yayasan PESAT mendirikan Taman Kanak-Kanak Sion Tridamarsari dengan motivasi akan mengKristenkan anak-anak nonKristen yang belajar di Taman Kanak-Kanak Sion Tridamarsari. Akan tetapi dengan semangat, kerja keras, dan perjuangan serta kepedulian ke empat orang perintis terhadap pendidikan anakanak di pedesaan, maka masyarakat dapat menerima kegiatan belajar mengajar dilaksanakan, sehingga pada akhirnya dapat membuahkan hasil yang baik dan Taman Kanak-Kanak Sion Tridamarsari dapat beroperasi dalam mengajar dan membimbing anakanak hingga saat ini. ${ }^{25}$

Pada tahun ajaran 2017/2018 jumlah peserta didik Taman Kanak-Kanak Sion Tridamarsari berjumlah 39 orang anak dari usia empat sampai enam tahun. Jumlah 39 orang anak tersebut tardiri dari 19 anak kelompok B dan 20 anak kelompok A. Dari jumlah tersebut 19 anak dikelompokan berdasarkan agama, maka secara keseluruhan anak yang beragam Kristen 13 orang, anak yang beragama Islam 17 orang dan anak yang beragama Budha 9 orang. ${ }^{26}$

Kegiatan keseharian dalam belajar mengajar yang d ilakasanakan di Taman KanakKanak Sion Tridamarsari berlangsung selama dua setengah jam belajar setiap hari dalam seminggu, yang kegiatannya dimulai dari hari senin sampai hari sabtu dengan jam belajar dimulai dari jam 8.30 WIB sampai 10.00 WIB.

Letak Taman Kanak-Kanak Sion Tridamarsari yaitu terletak di RT/RW 02/05 Dusun Purwosari Desa Sampetan Kecamatan Ampel Kabupaten Boyolali Provinsi Jawa Tengah. Taman Kanak-Kanak Sion Tridamarsari telah terdaftar sebagai salah satu lembaga pendidikan anak usia dini yang sah di Kecamatan Ampel Kebupaten Boyolali Provinsi Jawa Tengah, dengan NSS: 002030902028, NPSN: 20352937, dan Terakreditasi: B.Taman Kanak-Kanak Sion Tridamarsari memiliki status tanah hak milik, dan dengan luas tanah secara keseluruhan berukuran $328 \mathrm{~m}^{2}$, yang dibagi berdasarkan ukuran sebagai berikut, luas bangunan $178 \mathrm{~m}^{2}$, luas halaman $98 \mathrm{~m}$, luas kebun $42 \mathrm{~m}^{2}$, luas tempat bermain $10 \mathrm{~m}^{2} .^{27}$

Iman Kristen anak pada awal sebelum adanya penerapan pendidikan iman Kristen sangat jauh berbeda dengan setelah penerapan pendidikan agama Kristen. Sebelum itu anak-anak sering mengungkapkan kata-kata yang kurang baik di dengar, belum memiliki keberanian berdoa, suka melakukan perbuatan yang menyakiti temannya, tidak memiliki inisiatif untuk menolong temannya, bahkan tingkat pemahaman akan Yesus Kristus masih sangat minim. Pertumbuhan Iman anak saat itu belum nampak. ${ }^{28}$

\footnotetext{
${ }^{25}$ Wawancara dengan DP, Guru Taman Kanak-Kanak Sion Tridamarsari, Rabu 2 Mei 2018, Jam: 12.46)

${ }^{26}$ Data Murid Taman Kanak-Kanak Sion Tridamrsari Tahun Ajaran 2017/2018

${ }^{27}$ Profil Taman Kanak-Kanak Sion Tridamarsari

${ }^{28}$ Wawancara dengan NNA, Kepala Sekolah Taman Kank-Kanak Sion Tridamarsari, Selasa 15 Mei 2018, Jam: 17.43 WIB
} 
Banyak anak Kristen memang telah mengetahui bahwa Yesus Kristus adalah Juruselamat, tetapi anak-anak belum mengenal Yesus Kristus secara pribadi. Anak-anak batas memahami Yesus Kristus karena mendengar cerita dari orang tua. Sehingga dapat dikatakan anak-anak belum mengalami pertumbuhan iman. ${ }^{29}$

Menurut DP, perkembangan iman anak sebelum adanya penerapan akan pendidikan agama Kristen belum nampak, hal ini dikatakan DP karena anak-anak pada awalnya belum mengerti bahwa ketika mengalami sakit maka harus berdoa, selain itu anak-anak belum mengerti bahwa sebagai sesama maka perlunya hidup saling tolong menolong, karena iman anak tidak bisa dibuktikan dengan kata-kata saja tetapi harulah dengan menunjukan perbuatannya, salah satunya yaitu menolong orang lain. ${ }^{30}$

Menurut SW pertumbuhan iman Kristen anak sangat minim sekali, dikarenakan anak-anak tidak dikenalkan Yesus Kristus secara mendalam, anak-anak hanya diberikan pemahan mengenai Yesus Kristus sebatas perbuatan-perbuatan yang dahsyat seperti melakukan banyak mujizat-mujizat, tetapi anak-anak tidak diajak untuk mengenal Yesus Kristus lebih mendalam sehingga anak-anak memiliki suatu konsep dan pemahaman yang benar dalam Imannya. Anak-anak memang baik mengetahui siapa Yesus Kristus tetapi lebih dari itu anak-anak perlu untuk menjadikan Yesus Kristus sebagai Tuhan dan Juruselamat dalam hidupnya. ${ }^{31}$

Menurut EK kehidupan pribadi anak tidak lengkap kalau anak-anak memahami Yesus Kristus sebagai Tuhan dan Juruselamat dalam kehidupannya sebatas karena anakanak sering mendengar cerita dari orang tua ataupun guru disekolah. Anak-anak harus mengalami perjumpaan sendiri dengan Yesus Kristus.Diusia seperti sekarang, memang anak-anak tidak begitu bisa merasakan karya Yesus Kristus dalam kehidupannya.Tetapi anak-anak harus diajarkan bahwa pengaruh Yesus Kristus dalam hidupnya itu sungguh besar.Sejauh ini anak-anak belum dapat merasakan hal tersebut karena anak-anak masih berada dalam waktu bermainnya.Walaupun anak-anak mengetahui Yesus Kristus adalah Juruselamat tetapi anak-anak tidak mengerti bahwa ketika telah percaya kepada Yesus Kristus maka ada hal-hal yang perlu dilakukan dan tidak perlu dilakukan.Hal inilah yang belum ada dalam diri anak-anak tersebut. Sehingga dapat dikatakan pertumbuhan iman anak saat belum adanya pengenalan akan Yesus Kristus dalam hidupnya, maka iman anak tidak bertumbuh. Karena iman anak bertumbuh bukan sebatas mengetahui Yesus Kristus sebagai Tuhan dan Juruselamat dalam hidup, tetapi dapat mencerminkan imannya melalui pengandalannya kepada Yesus Kristus dalam kehidupannya dan juga perbuatannya kepada sesama. $^{32}$

\footnotetext{
${ }^{29}$ Wawancara dengan NNA, Kepala Sekolah Taman Kanak-Kanak Sion Tridamarsari, Selasa, 15 Mei 2018, Jam: 17.43 WIB

${ }^{30}$ Wawancara dengan DP, Guru Taman Kanak-Kanak Sion Tridamrsari, Jumat, 18 Mei 2018, Jam: 15.35 WIB

${ }^{31}$ Wawancara dengan SW, Guru Taman Kanak-Kanak Sion Tridamrsari, Rabu 23 Mei 2018, Jam: 10.20 WIB

${ }^{32}$ Wawancara dengan EK, Tutor FC Taman Kanak-Kanak Sion Tridamarsari, Rabu 23 Mei 2018, Jam: 19.53 WIB
} 


\section{Proses Penerapan Pendidikan Agama Kristen}

Proses penerapan pendidikan agama Kristen pada anak usia dini berbeda dengan penerapan pendidikan agama Kristen pada anak usia sekolah dasar atau selanjutnya, karena ketika anak telah masuk pada usia sekolah dasar atau selanjutnya maka pendidikan agama Kristen telah diterapkan sebagai salah satu mata pelajaran agama di sekolah. Berbeda dengan penerapan pada anak usia dini. Tetapi pada dasarnya dan intinya pembelajaran agama Kristen di sekolah dasar atau selanjutnya dan pembelajaran agama Kristen pada anak usia dini itu sama yaitu pembelajaran yang berfokus pada kehidupan Yesus Kristus yang adalah Tuhan dan Juruselamat dalam kehidupan setiap manusia, dan dengan tujuan menumbuhkan iman anak dan anak memiliki karakter Kristus dalam dirinya, bahkan lebih dari pada itu anak dapat mencintai Yesus Kritus secara lebih dan sungguh-sungguh sehingga menjadikan Yesus Kristus sebagai perioritas utama dan pertama dalam hidupnya. Dalam menerapakan pendidikan agama Kristen di Taman Kanak-Kanak Sion Tridamarsari para guru-guru selalu menerapkan dengan menggunakan metode bercerita yaitu yang dilakukan pada awal kegiatan atau kegitan pembukaan, selanjutnya pada kegiatan intiyang dilakukan yaitu pada saat penjelasan tema tidak terlepas dari penciptaan Tuhan atau, dan selanjutnya pada tahap terakhir yaitu saat recalling, anak-anak akan diberikan suatu nasihat dan motivasi yang berkaitan dengan sikap mencerminkan iman Kristen dalam hidupnya.Proses penerapan pendidikan agama Kristen dilaksanakan atau diterapkan setiap hari kegiatan belajar mengajar dengan menggunakan metode bercerita, ceramah, dan tanya jawab di Taman Kanak-Kanak Sion Tridamarsari yaitu dengan waktu dimulai dari jam 7.30 WIB sampai dengan jam 10.00 WIB. ${ }^{33}$ Waktu yang dimaksud adalah pada awal kegiatan (pembukaan), penerapan PAK dilakukan pada cerita karakter sesuai dengan buku kurikulum karakter yang disedikan oleh pihak sekolah, contohnya cerita tentang Yesus Menyembuhkan orang sakit, Yesus memberi makan lima ribu orang, saling memaafkan, saling menolong dengan waktu lima belas menit bercerita, selanjutnya pada waktu penjelasan tema (kegiatan inti), anak-anak akan diberikan pengenalan kepada Tuhan melalui tema-tema yang akan dipelajari saat kegiatan hari tersebut, misalnya berbicara tentang tema alam semesta, keluarga, diriku dan lain-lain, dan pada bagian terakhir penerapan PAK diterapkan adalah saat recalling, dalam recalling anak akan ditanyakan kesalahan yang telah dilakukan dan sudahkah anak menyadari bahwa perbuatannya adalah perbuatan yang salah.

Proses penerapan pendidikan agama Kristen di Taman Kanak-Kanak Sion Tridamarsari merupakan satu rancangan secara khusus dalam menumbuhkan iman Kristen anak-anak. Dalam mengembangkan pendidikan agama Kristen, guru tidak saja sebatas memberikan teori atau materi saja kepada anak-anak, tetapi guru juga terus mengontrol setiap pertumbuhan iman Kristen anak-anak sehari-hari, sehingga tujuan yang telah ditetapkan dapat tercapai. ${ }^{34}$

\footnotetext{
${ }^{33}$ Wawancara dengan NNA, Kepala Sekolah Taman Kanak-Kanak Sion Tridamarsari, Selasa 15 Mei 2018, jam: 17.43 WIB

${ }^{34}$ Wawancara dengan MJD, Guru Taman Kank-Kanak Sion Tridamarsari, Senin 28 Mei 2018, Jam: 10.35 WIB
} 
Pendidikan agama Kristen merupakan suatu pembelajaran yang sangat penting bagi pertumbuhan iman setiap peserta didik. Dengan penerapan pendidikan agama Kristen anak-anak akan bertumbuh iman Kristiani, yang artinya anak-anak bukan saja sebatas mengetahui siapakah Yesus Kristus? Tetapi dapat mengenal dan percaya kepadaNya sebagai Tuhan dan Juruselamat dalam kehidupan anak-anak. Selain dari itu, anak-anak dapat mengandalkan Yesus Kristus dalam kehidupan sehari-hari, contohnya anak-anak dapat berdoa meminta pertolongan kepada Yesus Kristus ketika salah satu teman yang sakit atau salah satu anggota keluarga mengalami sakit ataupun ketika mengalami suatu masalah. ${ }^{35}$

Penerapan pendidikan agama Kristen yang dilakukan dalam keseharian merupakan bagian untuk mengajarkan anak-anak agar dapat membedakan suatu perbuatan yang bersifat benar dan salah. Salah satu contohnya anak-anak dapat menegur temannya ketika melihat temannya mengganggu temannya yang lain atau anak dapat menasehati temannya ketika didapati salah satu temannya telah memukul temannya yang lain dan juag ketika ada yang mencuri barang milik temannya. Pendidikan agama Kristen ini juga bermanfaat bagi anak-anak dalam pertumbuhan imannya sejak usia dini. ${ }^{36}$

Proses penerapan pendidikan agama Kristen yang telah dilakukan baik dikegiatan pembukaan, kegiatan inti dan recalling sangat menentukan pertumbuhan iman anak-anak sejak dini, anak-anak dapat mengenal dan mempercayai Yesus Kristus dalam hidupnya, dan dapat menunjukan praktik imannya melalui mendoakan sesama, menolong orang lain bahkan menasehati temannya ketika melakukan kesalahan adalah suatu hal yang sangat penting terhadap anak-anak. ${ }^{37}$ Akan tetapi penerapan pendidikan agama Kristen yang telah dilakukan disekolahakan mengalamai hambatandalam menumbuhkan iman Kristen anakanak, jikalau kurangnya kesadaran dari orang tua terhadap pertumbuhan iman anak. Sebagai contohnya ketika disekolah guru akan mengajarkan anak-anak untuk sebelum melakukan segala sesuat harus telebih dahulu berdoa kepada Yesus Kristus, tetapi ketika anak dirumah maka keluarga tidak memperhatikan hal tersebut, keluargalebih sibuk dengan urusannya masing-masing sehingga tidak adanya pengontrolan dalam pertumbuhan iman anak. Hal inilah yang harus diperhatikan oleh pihak guru-guru. Guru-guru tidak hanya menumbuhkan iman anak disekolah, tetapi guru-guru membangun komunikasi dengan pihak orang tua dirumah agar dalam menumbuhkan iman anak, tidak saja dilakukan oleh pihak sekolah tetapi juga terus dibantu dengan kerjasama antara pihak sekolah dan pihak orang tua. ${ }^{38}$ Dalam menumbuhkan iman anak, guru-guru lebih banyak berperan sebagai motivator, sebagai sahabat, sebagai teladan, sebagai fasilitator, sebagai pembimbing dan sebagai penginjil dan sebagai gembalaa. Sebagai contohnya dalam

\footnotetext{
${ }^{35}$ Wawancara dengan MJD, Guru Taman Kank-Kanak Sion Tridamarsari, Senin, 28 Mei 2018, Jam: 10.35 WIB

${ }^{36}$ Wawancara dengan DP, Guru Taman Kanak-Kanak Sion Tridamarsari, Jumat 18 Mei 2018, Jam 15.35 WIB

${ }^{37}$ Wawancara dengan MJD, Guru Taman Kanak-Kanak Sion Tridamarsari, Senin 28 Mei 2018, Jam 10.55

${ }^{38}$ Wawancara dengan ED, Tutor FC Taman Kanak-Kanak Sion Tridamarsari, Rabu 23 Mei 2018, Jam: 19.53 WIB
} 
berperan sebagai penginjil, EK selalu mengajak anak-anak untuk memiliki kepercayaan kepada Yesus Kristus sebagai Juruselamat dalam hidup. Terkadang EK akan memanggil salah seorang anak untuk bertanya, bahwa dalam kehidupan manusia, seringkali manusia menyakiti hati Tuhan contohnya melawan orang tua, memukuli teman, mengeluarkan katakata kotor. Hal tersebut merupakan perbuatan dosa. Ketika melakukan dosa maka Tuhan tidak menyukai. Ketika menyakiti hati Tuhan, Tuhan tidak membenci manusia tetapi Tuhan memaafkan manusia dengan rela menebus kesalahan manusia dengan mengorbankan diriNya di Kayu Salib untuk menyelamatkan manusia dari dosanya. Untuk itu manusia perlu menyadari bahwa manusia hidup karena pertolonga Tuhan Yesus Kristus di atas Kayu Salib.

\section{Kesimpulan}

Berdasarkan hasil penelitian mengenai "Peranan Guru Dalam Menerapkan Pendidikan Agama Kristen Untuk Menumbuhkan Iman Anak Sejak Dini”, maka dapat disimpulkan bahwa pendidikan agama Kristen adalah hal yang sangatlah penting untuk diterapkan sejak dini untuk menumbuhkan iman anak. Penerapan pendidikan agama Kristen yang dilakukan adalah dengan cara bercerita dan ceramah.

Peranan guru merupakan hal yang sangat penting dalam membentuk pertumbuhan iman anak sejak dini. Peran-peran guru dalam menumbuhkan iman Kristen anak adalah, guru sebagai sahabat, guru sebagai gembala, guru sebagai penginjil, guru sebagai fasilitator, guru sebagai pembimbing, guru sebagai motivator dan guru sebagai teladan. Selain guru memilki peran-peran diatas, maka guru juga memiliki kriteria yaitu bartumbuh dalam Kristus, mengandalkan Roh Kudus, konsep diri Positif, mencintai anak-anak, menyadasri bahwa mendidik anak-anak adalah bentuk pelayanan terhadap panggilan Tuhan dalam hidup.

Tugas dan tanggung jawab dalam menumbuhkan iman anak tidaklah hanya tugas gereja tetapi tugas dari seorang guru yang telah menjadi percaya kepada Yesus Kristus sebagai Tuhan dan Juruselamat. Guru mendidik anak dengan bertumbuh dalam pengenalan akan Yesus Kristus sebagai Tuhan dan Juruselamat dalam hidup, dapat berdoa, dapat membedakan sesuatu yang benar dan tidak benar, anak dapat menolong sesamanya.

Berdasarkan penjelasan diatas disimpulkan bahwa peranan guru dalam dunia pendidikan bukan saja sekedar mengajar dan mendidik anak untuk memiliki intelektual yang baik tetapi membawa anak-anak untuk mengenal akan Yesus Kristus sebagai Tuhan dan Juruselamat dalam hidup sejak dini. Anak-anak diajarkan agar memiliki iman yang benar terhadap Yesus Kristus. Untuk itu dalam menumbuhkan iman anak melalui penerapan pendidikan agama Kristen di Taman Kanak-Kanak Sion Tridamarsari, maka guru memiliki peran yang baikuntuk anak-anak seperti guru menjadi sahabat, menjadi gembala, menjadi penginjil, guru menjadi fasilitator, guru menjadi pembimbing, guru menjadi motivator, guru menjadi teladan. 


\section{Daftar Pustaka}

Boehlke, Robert R. Sejarah Perkembangan Dan Praktek PAK: Dari Yohanes Amos Comenius Hingga Perkembangan PAK Di Indonesia. Jakarta: BPK-Gunung Mulia, 2011. . Sejarah Perkembangan Pikiran \& Praktek Paki. BPK Gunung Mulia, 1994.

Daniel, Nuhamara. Pembimbing Pendidikan Agama Kristen. Bandung: Jurnal Info Media, 2009.

Froebel, Friedrich. The Education of Man. Vol. 5. A. Lovell \& Company, 1910.

Groome, Thomas H. Christian Religious Education. BPK Gunung Mulia, 2015.

Harianto, GP. "Pendidikan Agama Kristen Dalam Alkitab Dan Dunia Pendidikan Masa Kini." Yogyakarta: Yasasan Andi (2012).

Hasan, Fuad. Koentjaraningrat, Metode-Metode Penelitian Masyarakat. Jakarta: Gramedia, 1970.

Homrighausen, Elmer George, and Ido Hendricus Enklaar. Pendidikan Agama Kristen. Badan Penerbit Kristen, 2015.

Hura, Sudiria, and Marde Christian Stenly Mawikere. "KAJIAN BIBLIKA MENGENAI PENDIDIKAN ANAK DAN HAKIKAT PENDIDIKAN ANAK USIA DINI." EDULEAD: Journal of Christian Education and Leadership 1, no. 1 (2020): 15-33.

Nainggolan, John M. Strategi Pendidikan Agama Kristen. Generasi Info Media, 2008.

Paulus, Lilik Kristianto. Prinsip \& Praktik Pendidikan Agama Kristen. Yogyakarta: Andi Offset, 2015.

Romini, Romini, and Ida Destariana Harefa. "MANFAAT PENGGUNAAN ALKITAB BERGAMBAR TERHADAP PERKEMBANGAN KEROHANIAN ANAK FUTURE CENTER USIA 7-9 TAHUN DI BULUH AWAR." EDULEAD: Journal of Christian Education and Leadership 1, no. 1 (2020): 1-14.

Sembiring, Maximus. Mengungkap Rahasia Dan Tips Manjur Menjadi Guru Sejati. Galangpress, 2008.

Sidjabat, B Samuel. Strategi Pendidikan Kristan. Yayasan ANDI, 1994.

Soetjipto, Raflis Kosasi. "Profesi Keguruan.” Jakarta: Rineka Cipta (2009).

Sugiyono, Prof Dr. "Metode Penelitian Pendidikan.” Pendekatan Kuantitatif (2010).

Sugiyono, S. "Metode Penelitian Pendidikan Pendekatan Kuantitatif, Dan R\&D." Alfabeta Bandung (2015).

Usman, Husaini, and Purnomo Setiady Akbar. Metodologi Penelitian Sosial. Bumi Aksara, 2008 . 